\title{
Effect of Cadmium on Growth Parameters and Plant Accumulation in Different Rice (Oryza sativa L.) Varieties in Sri Lanka
}

\author{
H.M.D.A.K. Herath ${ }^{*}$, D. C. Bandara ${ }^{1}$, P.A. Weerasinghe ${ }^{3}$ \\ M.C.M. Iqbal ${ }^{2}$ and H.C.D. Wijayawardhana ${ }^{3}$
}

\author{
Postgraduate Institute of Agriculture \\ University of Peradeniya \\ Sri Lanka
}

\begin{abstract}
Rice (Oryza sativa L.) has the ability to uptake and accumulate cadmium $(C d)$ in different amounts within the plant parts. A pot experiment was conducted to investigate the variations of plant growth and levels of accumulation of $C d$ among eight rice genotypes (new improved varieties-NIVs and traditional varieties- TVs) grown under different soil Cd levels. Two soil Cd concentrations (50 and $100 \mathrm{mg} / \mathrm{kg}$ ) were provided in the form of cadmium chloride and the effect of $\mathrm{Cd}$ on rice plant growth was measured with respect to the plant height, number of tillers, flag leaf chlorophyll content, leaf area of the flag leaf, and root dry weight. The soil without added Cd was considered as the control. The initial Cd concentration in the soil used was $1.958 \mathrm{mg} / \mathrm{kg}$. The total amount of Cd in unpolished rice grains, shoots and roots were analyzed with Graphite Furnace Atomic Absorption Spectrophotometer and Flame Atomic Absorption Spectrophotometer. The results revealed that the rice variety, soil $\mathrm{Cd}$ level and interactions between rice variety and $C d$ level significantly affected $(p<0.05)$ the plant height, flag leaf area, root dry weight and $C d$ accumulation. The variety Suwandel could not withstand soil Cd levels at $50 \mathrm{mg} / \mathrm{kg}$ and 100 $m g / k g$. Increasing soil Cd level reduced the plant height and root dry weight except in At 307. The variety Bg 300 was the lowest grain Cd accumulator without $C d$ chloride addition. Grain Cd accumulation in TV was high at $0 \mathrm{mg} / \mathrm{kg}$ level whereas NIV showed the highest accumulation at 50 and $100 \mathrm{mg} / \mathrm{kg} C \mathrm{Cd}$ levels. The shoot Cd level was increased with increasing soil Cd level. The Cd distribution within the rice plant is grains $<$ shoots $<$ roots.
\end{abstract}

Keywords: Accumulation, cadmium, growth, rice, varieties

\section{INTRODUCTION}

Heavy metals are important contaminants in the environment, especially in areas where there is high anthropogenic pressure. Cadmium is a non essential element and is the fifth most toxic metal to vertebrates and the fourth most toxic metal to vascular plants. It is believed that contamination of water sources and agricultural lands with fertilizers and agrochemicals for long periods of time is the main reason for accumulation of Cd. Bandara et al. (2008) and Premarathna et al. (2011) reported that the triple super phosphate (TSP) used by the Sri Lankan farmers carried 23.50 to $71.4 \mathrm{mg} / \mathrm{Cd} / \mathrm{kg}$ of $\mathrm{P}_{2} \mathrm{O}_{5}$. Also he further confirmed that

\footnotetext{
Department of Agricultural Biology, Faculty of Agriculture, University of Peradeniya, Sri Lanka Institute of Fundamental Studies, Hanthana Road, Kandy, Sri Lanka

Department of Plant Sciences, Faculty of Agriculture, Rajarata University of Sri Lanka, Puliyankulama, Sri Lanka

Corresponding author: dinumherath@yahoo.com
} 
commonly used weedicides in rice cultivation in Sri Lanka known as bispyribac sodium contains $0.5 \mathrm{mg} / \mathrm{l}$ of $\mathrm{Cd}$. Therefore, heavy $\mathrm{Cd}$ accumulation in agricultural soil can become dangerous to crops. When growing of plants in $\mathrm{Cd}$ polluted area, $\mathrm{Cd}$ is readily taken up by plant roots and translocated in to leaves in many plant species. Rice is the staple food in Sri Lanka and is considered to be a possible source of Cd intake (Chaney et al., 2004). The maximum permissible level of $\mathrm{Cd}$ in polished rice grain according to the Codex committee of the Food and Agriculture Organization of the United Nations (FAO) and by the WHO is $0.4 \mathrm{mg} / \mathrm{kg}$. Wu \& Zhang (2002) have reported that plant species and also genotypes within the species differ greatly in their tolerance to Cd stress. Sri Lanka has a genetically diverse rice collection with both traditional and new improved rice varieties and there is a lack of information available on grain $\mathrm{Cd}$ accumulation with different soil $\mathrm{Cd}$ levels and effect of $\mathrm{Cd}$ on growth performances of locally available rice genotypes. Thus this study was conducted to investigate the variations among rice varieties for $\mathrm{Cd}$ tolerance with respect to plant growth parameters and to determine the $\mathrm{Cd}$ uptake and accumulation by selected rice varieties grown in Sri Lanka.

\section{MATERIALS AND METHODS}

The study was performed as a pot trial in a plant house of the Department of Plant Sciences, Faculty of Agriculture, Rajarata University of Sri Lanka from April to August 2012 with eight rice (Oryza sativa L.) varieties. The soil was collected from the faculty field and samples were analyzed for soil basic properties and specially to detect the available $\mathrm{Cd}$ content. Twenty five kilograms of soil was placed in each pot and $\mathrm{Cd}$ in the form of $\mathrm{CdCl}_{2} .2$ $1 / 2 \mathrm{H}_{2} \mathrm{O}$ was added to soil to obtain following Cd levels as; $50 \mathrm{mg} \mathrm{Cd} / \mathrm{kg}$ of soil (T2) and 100 $\mathrm{mg} \mathrm{Cd} / \mathrm{kg}$ of soil (T3) and the soil receiving no external $\mathrm{Cd}$ was used as the untreated soil (T1). The pots once filled with soil were thoroughly mixed with water contaminated with exact amount of $\mathrm{CdCl}_{2} .21 / 2 \mathrm{H} 2 \mathrm{O}$ based on the treatment and submerged in water for 48 hours before the rice seedlings were transplanted in them. Eight different rice varieties were used in this experiment. Those were $\mathrm{Bg} 300$, At307, Bg352 and $\mathrm{Bg} 358$ as new improved rice varieties and Suwadel, Kaluheenati, Pachchaperumal and Kuruluthudu as traditional rice varieties. Seeds were surface sterilized with $20 \%$ clorox and soaked in water for $48 \mathrm{hrs}$ and germinated in parachute trays. After 14 days, plants with two leaf stage were transplanted into the pots. The pot soil was maintained under submerged conditions during the whole growth period. The pots were arranged as a Two Factor Factorial Experiment with Completely Randomized Design with three replicates. Fertilizers were provided according to the Department of Agriculture, Sri Lanka recommendations. During the vegetative growth plant height, leaf area of the flag leaf, number of tillers, flag leaf chlorophyll content were measured. After the ripening stage, rice plants were uprooted and root dry weight was measured, Finally, Cd accumulation in rice grain, shoot and root were measured using the following method. $0.3 \mathrm{~g}$ of plant samples, were put on microwave digester (Model: Milestone start D) and digested by following modified US EPA method 3052. The sample Cd concentration was recorded using a GF-AAS (Model: GBC GF3000) at IFS, Kandy.

\section{RESULTS}

\section{Effect of Cd on plant growth parameters}

Experimental results of the plant height data (Fig. 1) showed that Bg 300, Bg 352, Bg 358, Kaluheenati, Pachchaperumal and Kuruluthudu reduced their plant height with increasing 
soil Cd levels. Both Bg 300 and Bg 358 reduced their height significantly with the increasing soil Cd level. Even though Bg 352, kaluheenati and kuruluthudu reduced their height with increasing soil $\mathrm{Cd}$, the reduction of plant height from no addition of $\mathrm{Cd}$ to $50 \mathrm{mg} / \mathrm{kg} \mathrm{Cd}$ was not significant. However, this reduction was significant from $50 \mathrm{mg} / \mathrm{kg}$ soil Cd to $100 \mathrm{mg} / \mathrm{kg}$. Addition of Cd did not significantly affect the plant height of At 307 . Even though $50 \mathrm{mg} / \mathrm{kg}$ $\mathrm{Cd}$ addition reduced the plant height of At 307, there was no significant difference in plant height for both no addition of cadmium salt and $100 \mathrm{mg} / \mathrm{kg} \mathrm{Cd}$ addition.

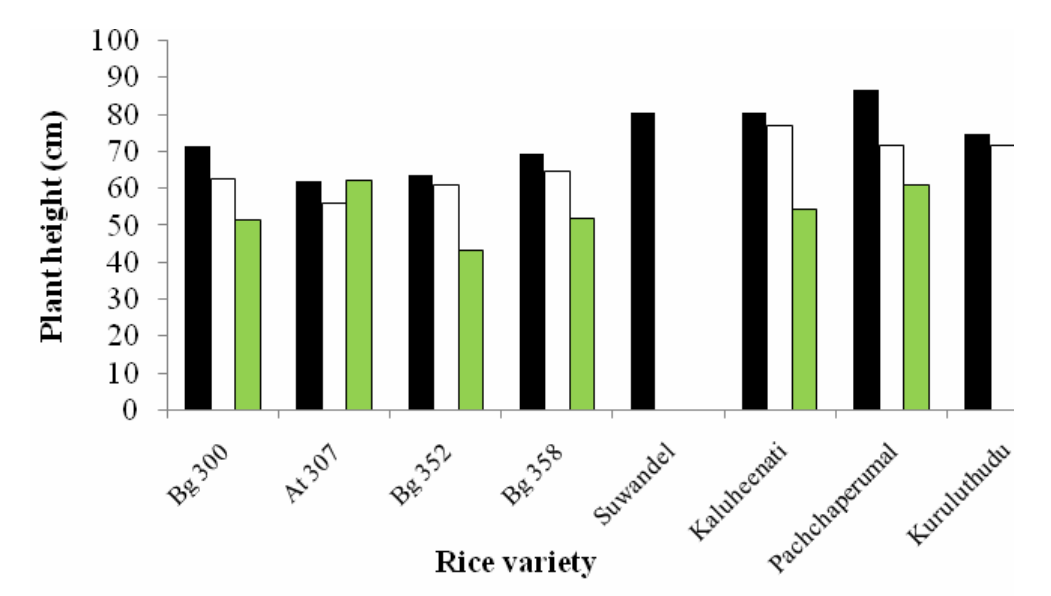

- $0 \mathrm{mg} / \mathrm{kg} \quad \square 50 \mathrm{mg} / \mathrm{Kg} \quad \square 100 \mathrm{mg} / \mathrm{kg}$

\section{Fig. 1. Varietal response to $\mathrm{Cd}$ on plant height}

Flag leaf chlorophyll content of different rice cultivars showed (Fig. 2) different responses with increasing soil $\mathrm{Cd}$ level. With the increasing soil $\mathrm{Cd}$ level, flag leaf chlorophyll content wasn't significantly reduced in Bg 300, At 307, Bg 358, Kaluheenati and Pachchaperumal. At 307, Bg 358, Kaluheenati and Pachchaperumal showed higher SPAD value with 50 $\mathrm{mg} / \mathrm{kg}$ soil Cd than in both no addition of Cd and $100 \mathrm{mg} / \mathrm{kg} \mathrm{Cd}$ treatments. But Bg 352 and Kuruluthudu showed the reduction of flag leaf chlorophyll content with increasing soil $\mathrm{Cd}$ levels. Both of these two rice varieties showed the highest chlorophyll content at zero addition of cadmium chloride and the lowest chlorophyll content at $100 \mathrm{mg} / \mathrm{kg} \mathrm{Cd}$ treatment.

The leaf area results revealed that rice variety, soil $\mathrm{Cd}$ level and variety $\mathrm{x} \mathrm{Cd}$ interaction significantly affected average leaf area of the eight tested rice varieties (Fig. 3). Increasing soil Cd level reduced the average leaf area of all tested rice varieties except in Suwandel.

This reduction was highly significant for $\mathrm{Bg} 300$ and $\mathrm{Bg}$ 358. When the soil $\mathrm{Cd}$ level changed from no addition of cadmium chloride to $50 \mathrm{mg} / \mathrm{kg}$ soil $\mathrm{Cd}$, the reduction of leaf area was significant for both At 307 and Pachchaperumal. However, this reduction was not significant for Bg 352, Kaluheenati and Kuruluthudu. Although the reduction of leaf area was not significant when soil $\mathrm{Cd}$ is increased from 50 to $100 \mathrm{mg} / \mathrm{kg}$ for At 307, this reduction was significant for Bg 352 and Kuruluthudu. 


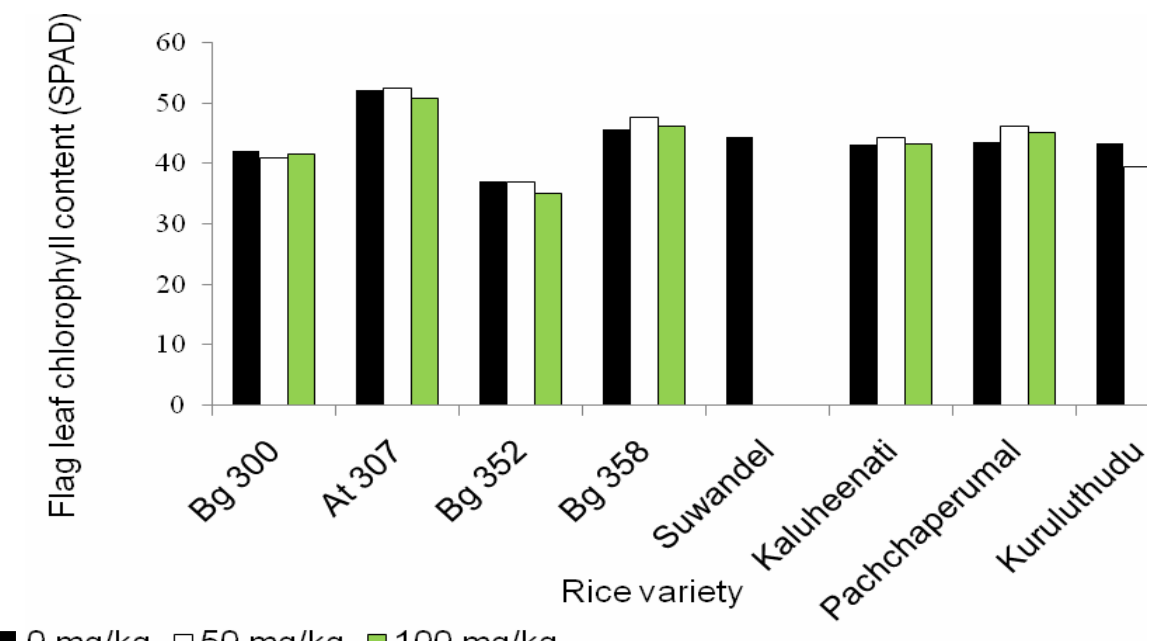

$0 \mathrm{mg} / \mathrm{kg} \quad \square 50 \mathrm{mg} / \mathrm{kg} \quad \square 100 \mathrm{mg} / \mathrm{kg}$

\section{Fig. 2. Varietal response of $\mathrm{Cd}$ on flag leaf chlorophyll content}

Fig. 3 shows the variation of leaf area with tested three soil Cd levels.

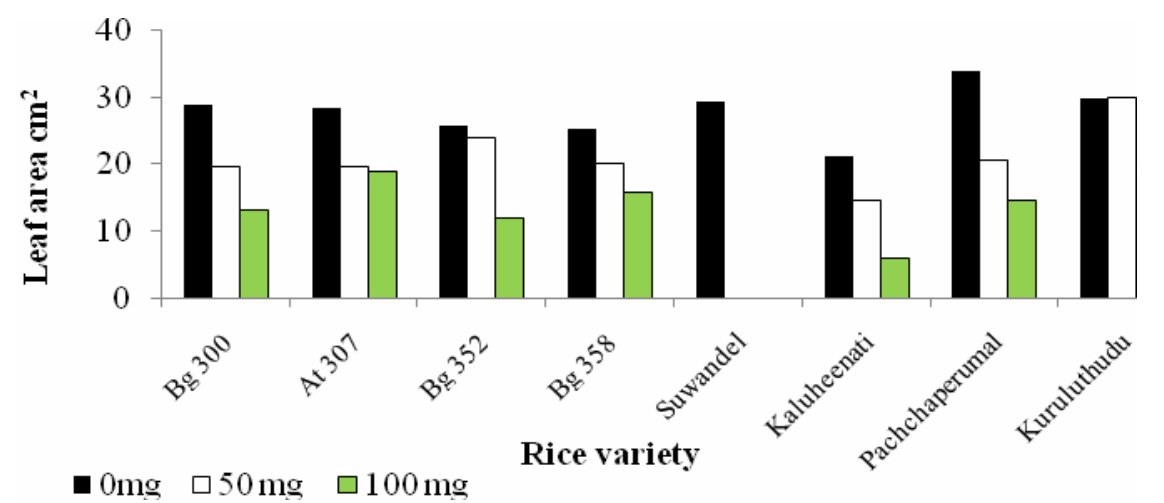

Fig. 3. Variation of leaf area with different soil Cd levels

When considering the tiller number, increasing soil Cd level reduced the number of tillers. This reduction was not significant for Bg 300, At 307, Kaluheenati, Pachchaperumal and Kuruluthudu (Fig. 4). For Bg 352 and Bg 358 there was a significant reduction of tiller number when the soil $\mathrm{Cd}$ level is increasing. When the soil $\mathrm{Cd}$ level is changing from 0 $\mathrm{mg} / \mathrm{kg}$ to $50 \mathrm{mg} / \mathrm{kg}$ both $\mathrm{Bg} 352$ and $\mathrm{Bg} 358$ reduced the number of tillers, but this reduction was not significant for both these two varieties. However, there was a significant reduction of tiller number observed in these two rice varieties when the soil $\mathrm{Cd}$ changed from 50 to $100 \mathrm{mg} / \mathrm{kg}$. 


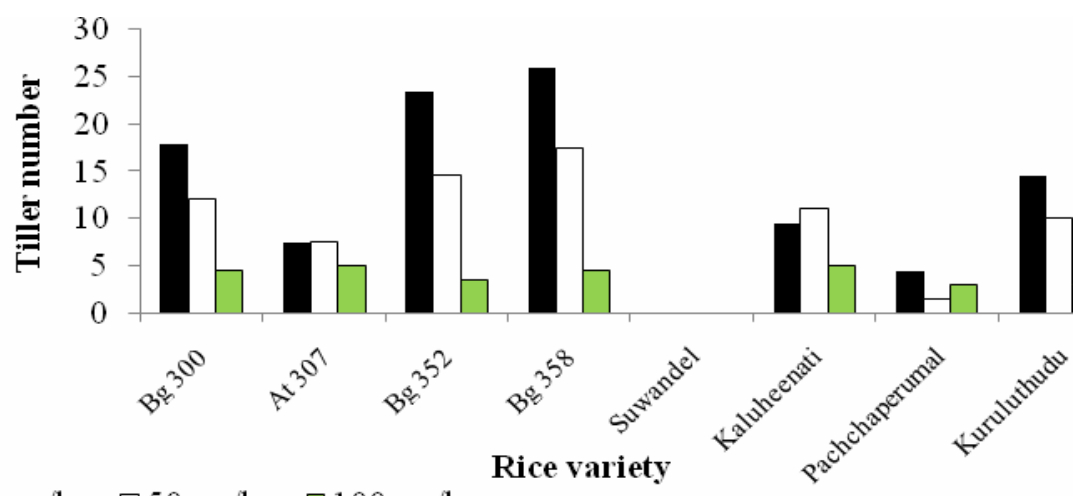

$0 \mathrm{mg} / \mathrm{kg} \quad \square 50 \mathrm{mg} / \mathrm{kg} \quad \square 100 \mathrm{mg} / \mathrm{kg}$

\section{Fig. 4. Variation of number of tillers with different soil Cd levels}

Root dry weight results (Fig. 5\& 6) revealed that, rice plants reduced their root dry weight when the soil Cd level is increasing. Bg 358 significantly reduced their root dry weight with increasing soil Cd level. Similarly Bg 300 reduced their root dry weight when soil Cd was changed from 0 to $50 \mathrm{mg} / \mathrm{kg}$. However, this reduction was not significant but the increasing soil Cd from 50 to $100 \mathrm{mg} / \mathrm{kg}$ caused the significant reduction of root dry weight for $\mathrm{Bg} 300$. Variety At 307 responded differently to the soil Cd level than other varieties. This variety has significantly reduced their root dry weight when the soil $\mathrm{Cd}$ level changed from 0 to 50 $\mathrm{mg} / \mathrm{kg}$. Although this variety increased the root dry weight from $50 \mathrm{mg} / \mathrm{kg} \mathrm{Cd}$ treatment to $100 \mathrm{mg} / \mathrm{kg}$ treatment numerically, this increase was also not significant. Though $\mathrm{Bg} 352$ significantly reduced the root dry weight when the soil Cd level is $50 \mathrm{mg} / \mathrm{kg}$, Kaluheenati, Pachchaperumal and Kuruluthudu also behaved in similar pattern. Further, these four rice varieties showed the reduction of root dry weight when the soil Cd level was 50 to 100 $\mathrm{mg} / \mathrm{kg}$ but this reduction was also not statistically different. Fig. 6 shows the variation of root dry weight with increasing soil Cd level.

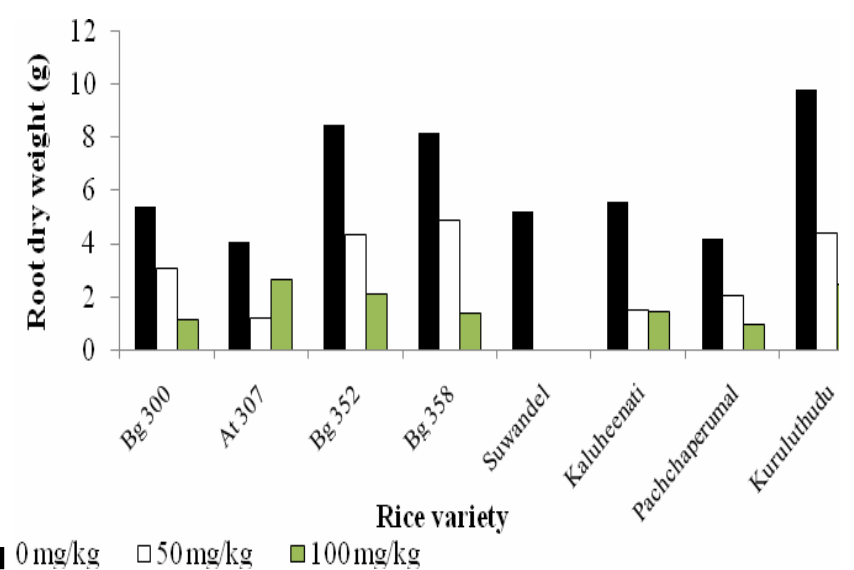

Fig. 5. Varietal response to $\mathrm{Cd}$ on root dry weight 


\section{Varietal Response to Cd Accumulation and Distribution within Rice Plant Body}

The experimental results of the average $\mathrm{Cd}$ accumulation of unpolished rice grains of the eight rice cultivars with three different soil Cd levels are shown in Fig. 7. According to the results, rice variety, soil Cd levels and the interaction between rice variety and soil Cd levels significantly affected grain $\mathrm{Cd}$ accumulation. The total grain $\mathrm{Cd}$ content in each rice variety of Bg 300, At 307, Bg 352, Bg 358, Kaluheenati, Pachchaperumal and Kuruluthudu were statistically different with the three soil Cd levels. Generally, the mean grain Cd levels increased with increasing soil Cd levels except variety in $\mathrm{Bg} 300$. In $\mathrm{Bg} 300$, the grain $\mathrm{Cd}$ content in $100 \mathrm{mg} / \mathrm{kg}$ soil Cd was lower $(2.26 \mathrm{mg} / \mathrm{kg})$ than the $50 \mathrm{mg} / \mathrm{kg}(2.719 \mathrm{mg} / \mathrm{kg})$ soil Cd. In At 307, Bg 352, Bg 358, Kaluheenati, Pachchaperumal and Kuruluthudu grain Cd content increased with increasing soil Cd concentration. The mean $\mathrm{Cd}$ content in all tested rice shoots except in variety Suwandel was highly statistically different at all three soil Cd treatments (Fig. 8). For all tested rice varieties the mean shoot $\mathrm{Cd}$ content was increased significantly with increasing soil Cd levels.

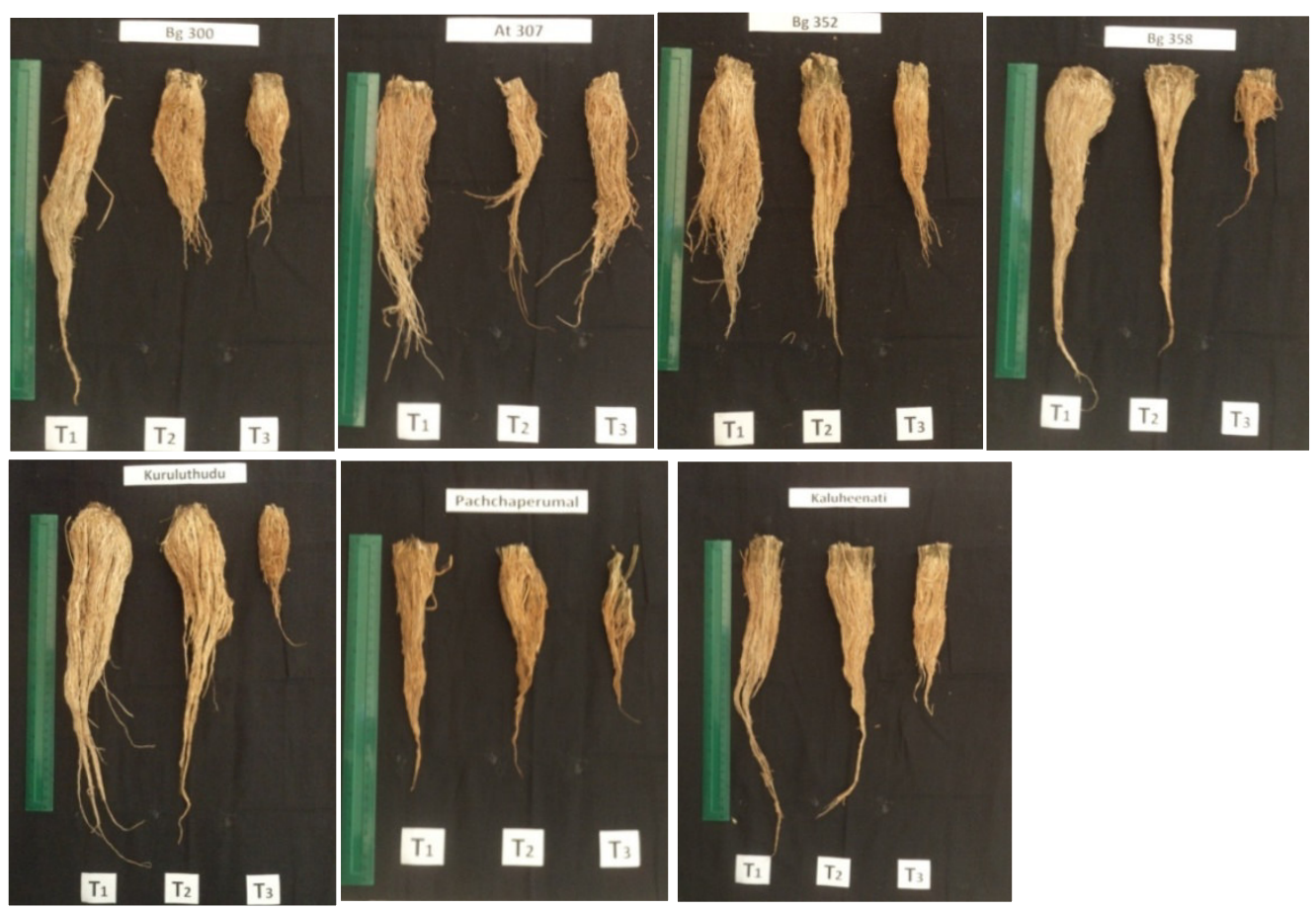

Fig. 6. Varietal response to $\mathrm{Cd}$ on root dry weight 


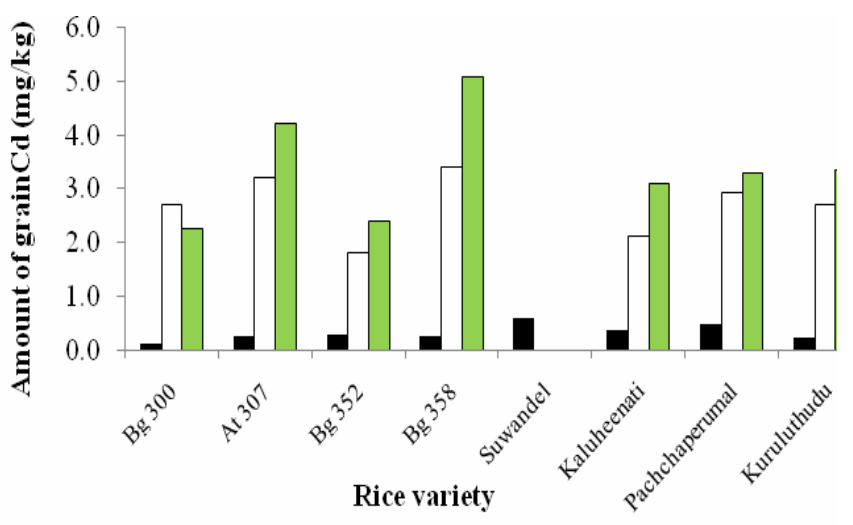

$0 \mathrm{mg} \quad \square 50 \mathrm{mg} / \mathrm{Kg} \quad \square 100 \mathrm{mg} / \mathrm{kg}$

\section{Fig. 7. Average grain Cd content in rice varieties with different soil Cd levels}

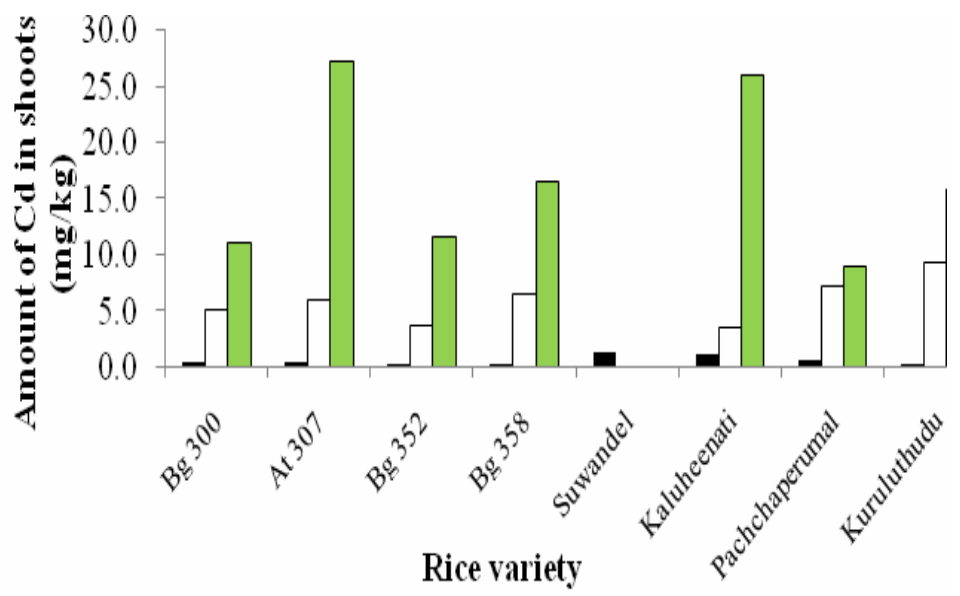

- $0 \mathrm{mg} \quad \square 50 \mathrm{mg} / \mathrm{Kg} \quad \square 100 \mathrm{mg} / \mathrm{kg}$

Fig. 8. Average shoot $\mathrm{Cd}$ content in rice varieties with different soil $\mathrm{Cd}$ levels

Cd content in roots of all tested rice varieties except in Suwandel was highly statistically different at the tested soil Cd levels. Results obtained from the study showed that variety $\mathrm{Bg}$ 300, At 307 and Kuruluthudu have increased their Cd accumulation with increasing soil Cd levels. Other rice varieties except Suwandel accumulated lower amount of Cd in their roots at $100 \mathrm{mg} / \mathrm{kg}$ soil Cd treatment than the $50 \mathrm{mg} / \mathrm{kg}$ soil Cd treatment.

It has been reported that the average $\mathrm{Cd}$ accumulation in rice roots were much higher than in stems and leaves and rice grains (Liu et al., 2003). The present study too confirmed this phenomenon; it showed that all the tested rice varieties accumulated $\mathrm{Cd}$ in the sequence of grain $<$ shoot $<$ root for every soil Cd level treated i.e. rice grains accumulated the lowest and the roots accumulated the highest. Although Suwandel variety completely died with 50 and $100 \mathrm{mg} / \mathrm{kg}$ soil $\mathrm{Cd}$ levels, it showed the same sequence with zero addition of cadmium chloride. So the results obtained from the study indicated that a great proportion of $\mathrm{Cd}$ taken 
up by rice plant was retained in roots. The Cd concentration fell rapidly from root to grains along rice plants and only a very small proportion of $\mathrm{Cd}$ taken by root was transferred to grain. So the concentration of $\mathrm{Cd}$ in grain was very low compared with other parts of the rice plant.

\section{DISCUSSION}

It has been shown that $\mathrm{Cd}$ is strongly phytotoxic and causes growth inhibition and even plant death (Sanita di Toppi \& Gabrielli, 1999). In general, Cd in plants reduces the growth both in roots and stems. This effect is partly due to the suppression of the elongation growth rate of cells, especially in the stem, because of an irreversible inhibition exerted by $\mathrm{Cd}$ on the proton pump responsible for the process (Aidid\& Okamoto, 1992). Liu et al. (2007)conducted the same experiment using six rice cultivars with $100 \mathrm{mg} / \mathrm{kg}$ soil $\mathrm{Cd}$ and concluded that toxicity effect of Cd on plant height is varietal dependent; the present study also proved this result. Further, Shao Guo-sheng et al (2007) did a hydroponic study to investigate Cd accumulation and its toxicity in rice on the Brittle Culml ( $b c 1)$ gene-a fragile rice mutant and its wild type with $0,0.1,1.0$ and $5.0 \mu \mathrm{mol} / \mathrm{L} \mathrm{Cd}$ levels and they concluded that both rice genotypes substantially inhibited the plant growth under high $\mathrm{Cd}$ levels (at 1.0 and $5.0 \mu \mathrm{mol} / \mathrm{L} \mathrm{Cd}$ levels).

Liu et al.(2007) have reported that the effect of Cd on dry matter accumulation of rice plants differed with rice cultivar, rice growth stage and plant organ. Results of the present study also revealed significant root dry weight reduction between no addition of cadmium chloride and $50 \mathrm{mg} / \mathrm{kg} \mathrm{Cd}$ treatment except in $\mathrm{Bg} 300$. The same result was further observed with no addition of cadmium chloride and $100 \mathrm{mg} / \mathrm{kg} \mathrm{Cd}$ treatment except in At 307. Further there was a significant difference among rice genotypes with no addition of cadmium chloride and $50 \mathrm{mg} / \mathrm{kg} \mathrm{Cd}$ treatments, but there was no observed significant difference among plant genotypes at $100 \mathrm{mg} / \mathrm{kg}$ soil Cd treatment. Roots responded differently to the soil Cd stress, here some plant genotypes showed comparatively high tolerance (Bg 300, At 307 and Kuruluthudu) than others to $100 \mathrm{mg} / \mathrm{kg}$ soil Cd treatment while some genotypes showed the slight toxicity (Bg 352, Bg 358, Kaluheenati and Pachchaperumal). Yu-jing et al. (2004) also observed a significant difference of rice root biomass with $0 \mathrm{mg} / \mathrm{kg}, 5 \mathrm{mg} / \mathrm{kg}$ and 10 $\mathrm{mg} / \mathrm{kg}$ soil Cd addition. They further reported that the addition of $10 \mathrm{mg} / \mathrm{kg} \mathrm{Cd}$ to the soil significantly reduced the root biomass.

When the growing medium $\mathrm{Cd}$ concentrations are different, rice plant can accumulate different amounts of $\mathrm{Cd}$ in their grains. Different literature has reported different levels of rice grain $\mathrm{Cd}$ with different $\mathrm{Cd}$ treatments. As an example, Jing et al (2009) reported that the mean grain $\mathrm{Cd}$ in unpolished rice grains of 110 cultivars as $0.022 \mathrm{mg} / \mathrm{kg}$ for paddy soils which contains $0.15 \mathrm{mg} / \mathrm{kg}$ soil Cd. Areo \& Ae (2003) have reported that the mean grain Cd content in 31 different rice cultivars as $2.14 \mathrm{mg} / \mathrm{kg}$ (for brown rice) with $0.9 \mathrm{mg} / \mathrm{kg}$ soil Cd and $3.11 \mathrm{mg} / \mathrm{kg}$ with $7.4 \mathrm{mg} / \mathrm{kg}$ soil Cd. Further they have reported that the variety Rathal (a traditional variety grown in Sri Lanka) accumulates 2.12 and $3.34 \mathrm{mg} / \mathrm{kg} \mathrm{Cd}$ in their grains in the same study. When comparing these values with the present results, the mean grain $\mathrm{Cd}$ content in $100 \mathrm{mg} / \mathrm{kg}$ soil $\mathrm{Cd}(3.376 \mathrm{mg} / \mathrm{kg})$ is nearly similar to the grain Cd content in Rathal $(3.34 \mathrm{mg} / \mathrm{kg})$ for $7.4 \mathrm{mg} / \mathrm{kg}$ soil Cd. In some parts of China, soil Cd content is up to $26 \mathrm{mg} / \mathrm{kg}$ and the highest $\mathrm{Cd}$ in rice grains was reported as $2.4 \mathrm{mg} / \mathrm{kg}$ (Jin, 2002: Yu- jing et al., 2004).

The maximum permissible level of $\mathrm{Cd}$ in polished rice grain according to the "Codex Alimentarius" Committee of the Food and Agriculture Organization of the United Nations 
(FAO) and by the World Health Organization (WHO, 2008) is $0.4 \mathrm{mg} / \mathrm{kg}$. However, Bg 300, At 307, Bg 352, Bg 358, Kaluheenati and Kuruluthudu did not exceed the WHO permissible level, but Suwandel and Pachchaperumal exceeded the permissible level with no addition of cadmium chloride.

During the last decade, a significant increase in the number of CKD patients from the North Central Province (NCP) of Sri Lanka has become a major environmental health issue of national concern. Exposure to a combination of factors that are toxic to the kidney seems to cause this kidney disease. Toxic factors identified up to now include arsenic, cadmium and nephrotoxic agrochemicals (WHO, 2011). In some areas in China and Thailand, production of highly $\mathrm{Cd}$ polluted rice and renal dysfunctions among populations were reported (Nordberg et al., 1997; Jin et al., 2002; Honda et al., 2010).

\section{CONCLUSIONS}

In the present experiment, the rice plants exposed to higher levels of $\mathrm{Cd}$ showed growth inhibition in plant height, chlorophyll content in flag leaf, leaf area, number of tillers and root dry weight.

$\mathrm{Cd}$ concentration in different cultivars responded differently to increasing soil Cd levels. The $\mathrm{Bg} 300$ accumulated lower amount of $\mathrm{Cd}$ in normal soil conditions, therefore, due to this phenomenon it could be concluded that $\mathrm{Bg} 300$ is the safest for human consumption than the other tested rice varieties. Further $\mathrm{Bg} 300$ accumulated low amount of $\mathrm{Cd}$ in their grains at the $100 \mathrm{mg} / \mathrm{kg}$ soil $\mathrm{Cd}$. Therefore, this variety is the most suitable to grow in highly $\mathrm{Cd}$ polluted locations among other tested varieties of rice.

Roots accumulate the highest amount of $\mathrm{Cd}$ than shoots and grains and distributed $\mathrm{Cd}$ as grains $<$ shoots $<$ roots for all tested soil Cd levels. Both new improved and traditional rice varieties behaved similarly.

Among the tested varieties $\mathrm{Bg}$ 300, At 307 and Kuruluthudu were the most tolerant rice varieties while $\mathrm{Bg} 352, \mathrm{Bg} 358$, Kaluheenati and Pachchaperumal were the less tolerant varieties. Among tested rice varieties At 307 was the highly tolerant variety to soil Cd stress because At 307 could compensate both shoot and root growth when soil Cd level was 100 $\mathrm{mg} / \mathrm{kg}$. Rice variety Suwandel is a highly sensitive variety than the other tested rice varieties for both 50 and $100 \mathrm{mg} / \mathrm{kg}$ soil Cd levels because these two soil Cd levels are toxic to this variety. Thus this variety could not withstand at both 50 and $100 \mathrm{mg} / \mathrm{kg}$ soil Cd levels.

Without addition of external $\mathrm{Cd}$ as cadmium chloride, traditional rice varieties always accumulated the highest amount of $\mathrm{Cd}$ within all plant parts (i.e rice grains, shoots and roots) than new improved rice varieties. Therefore, the traditional rice varieties can accumulates a considerable amount of $\mathrm{Cd}$ within their body than new improved rice varieties with normal soil conditions.

\section{ACKNOWLEDGEMENTS}

This work was supported by the Institute of Fundamental Studies, Hantana, Road, Kandy, Sri Lanka and granted by Research and Publication committee of Rajarata University of Sri Lanka. 


\section{ffect of Cadmium on Growth of Rice}

\section{REFERENCES}

Aidid, S.B.,Okamoto, H.(1992). Effect of lead, cadmium and Zinc on the electric membrane potential at the xylem/symplast interface and cell elongation of Impatiens balsamina. Environmental and Experimental Botany, 32, 439 - 448.

Akesson, A. (2011). Cadmium Exposure in the Environment: Renal Effects and the Benchmark Dose. Encyclopedia of Environmental Health.465-473.

Areo, T., and Ae, N. (2003). Genotypic Variations in Cadmium Levels of Rice Grain.Soil Science and Plant Nutrition.49, 473 - 479.

Bandara, J.M.R.S., Senevirathna, D.M. A., Dasanayake, D.M.R.S.V., Herath, V. and Bandara, J.M.R.P. (2008). Cronic Renal Failure in Cascade Irrigation Systems in Sri Lanka Associated with Elevated Dietary Cadmium Levels in Rice and Fresh Water Fish (Tilapiya). Environmental Geochemistry and Health. 30, 465 - 478.

Chaney, R.L., Reeves, P.G., Ryan, J.A., Simmons, R.W., Welch, R.M., Angel, J.S. (2004). An Improved Understanding of Soil Cd Risk to Humans and Low Cost Methods to Remediate Soil Cd Risks.Biometals.17, 549 - 553 pp

Guo-sheng, S., Ming-xue, C., Xiu-fu, Z. (2007). Cadmium Accumulation and Its Toxicity in Brittle culm1 (bc1), A Fragile Rice Mutant.Rice Science.14(3), 217 - 222.

Honda, R., Swaddiwudhipong, W., Nishjom.,Mahasakpan, P., Teeyakasem, W., Ruangyuttikarn, W., Satarug, S., Padungtod, C., Nakagawa, H. (2010). Cadmium Induced Renal Dysfunction among Residents of Rice Farming Area Downstream from ZincMineralized belt in Thailand, Toxicology letters. 198, 26 - 32.

Jin, T., Nordberg, M. (2002). Cadmium Biomonitoring and Renal Dysfunction among A Population Environmentally Exposed to Cadmium from Smelting in China (China Cad). Biometals. 15, 397 - 410.

Jing, S.H.I., Lianqing, L.I., Genxing, P.A.N. (2009). Variation of Grain Cd and Zn Concentrations of 110 Hybrid Rice Cultivars Grown in a Low- Cd Paddy Soil. Journal of Environmental Sciences.21, 168 - 172.

Liu, J., Li, K., Xu, J. (2003).Interaction of Cd and Five Mineral Nutrients for Uptake and Accumulation in Different Rice Cultivars and Genotypes.Field Crops Research. 83, 271 281.

Liu, J., Qian, M., Cai, G. (2007). Uptake and Translocation of Cd in Different Rice Cultivars and the Relation with Cd Accumulation in Rice Grain.Journal of Hazardous Materials. 143, $443-447$.

Nordberg, G., Jin, T., Bernard, A., Fierens, S., Buchet, J.P., Ye, T. (1997). Low Bone Density and Renal Dysfunction Following Environmental Cadmium Exposure in China.Ambio.31, 478 - 481. 
Premarathna, H.M.P.L., Hettiarachchi, G.M. and Indraratne, S.P. (2011). Trace Metal Concentration in Crops and Soils Collected from Intensively Cultivated Areas of Sri lanka.Pedologist.230-240.

Sanita di toppi, L. and Gabbrielli, R. (1999) Response to Cd in higher plants, Environmental Experimental Botany. 41,105 - 130.

WHO. (2008). Chronic Kidney Disease of Unknown Aetiology (CKDu), A New Threat to Health.Retrived May 20, 2012 from http://www.searo.who.int/ linkFiles /News_LettersCKDu.pdf.

Wu,F.b., Zhang,G.P. and Peter,D. (2002). Four barley genotypes respond differently to cadmium:lipid peroxidation and activities of antioxidant capacity.Environmental Experimental Botany.50, 67 - 77.

Yu- jing, C.U.I., Yong-guan, Z.H.U., Andew Smith, F., Sally E Smith. (2004). Cadmium Uptake by Different Rice Genotypes that Produce White or Dark Grains.Journal of Environmental Sciences.16(6), 962 - 967. 